\title{
Evaluation and Response of Farmers on The Application of Biosecurity System for Layer Chicken Farming in Lendah District Kulonprogo
}

\author{
Francy Risvansuna ${ }^{1, *}$, Yus Peisal Nur Hikmat ${ }^{1}$, and Gawong Satya ${ }^{1}$ \\ ${ }^{1}$ Universitas Muhammadiyah Yogyakarta, Department of Agribusiness, 55183 Yogyakarta, Indones
}

\begin{abstract}
Poultry farming has the risk of being attacked by various diseases. One effort to protect the poultry, particularly layer chickens is by implementing a biosecurity system to prevent death due to diseases [1]. The area where most breeders have implemented a biosecurity system is located in Lendah, Kulonprogo because, in 2015, chickens in the district were attacked by Newcastle disease called Tetelo. This study aims to evaluate the implementation of the biosecurity system by analyzing the conditions and the success rate of this system on layer chicken farming, as well as the attitudes of breeders toward the system. The respondents were gathered using census, and the data were analyzed by measuring variables in aspects of biosecurity conditions using a rating scale. The Spearman Rank measured the correlation, whereas breeders' attitudes toward the implementation of biosecurity were measured qualitatively. The results showed that the implementation of the biosecurity system was at a moderate level, and chicken mortality was quite high. The attitudes of the breeders toward the layer chicken's biosecurity system as a whole belonged to the good category. In conclusion, layer chicken breeders had a positive response to the biosecurity system.
\end{abstract}

\section{Introduction}

One type of farming require to be developed to meet the needs of the Indonesian people is layer chickens as the demand for chicken eggs continues to increase from year to year. In a row over the past three years, from 2015 to 2017, the demands for chicken eggs per capita per year in Indonesia were: as follows, $100.88 \mathrm{~kg} /$ capita/year, 103.12 $\mathrm{kg} /$ capita/year, and $110.19 \mathrm{~kg} /$ capita/year. Therefore, this business has considerable opportunities. However, layer chickens have a high risk of failure due to diseases. The diseases attacking layer chickens are avian influenza and Newcastle disease or commonly in Javanish called Tetelo [2].

The diseases can harm chicken breeders, such as decreased productivity and death of chickens both on a small and large scale. Thus, a system is needed to prevent the emergence of the diseases in order to reduce the potential economic loss.

\footnotetext{
*Corresponding author: francy@umy.ac.id
} 
The effort to protect layer chickens is carried out through implementing a biosecurity system aiming to prevent the attack of deadly diseases. The application of the biosecurity system in laying hens aims to protect chickens from various diseases. The implementation of biosecurity is the first line of defense against avian influenza (HPAI), which is highly pathogenic in poultry farming [3]. Although, in a study in Cambodia, the implementation of basic biosecurity could not completely resolve the spread of diseases caused by viruses such as the Newcastle or called Tetelo [4] .

One area that has implemented a biosecurity system since 2014 is Lendah District in Kulonprogo Regency. This area is a center for laying hens. All layer chicken farms in Lendah district are small because they have less than 10,000 chickens. However, in 2015, hundreds of hens suddenly died due to Tetelo. It caused breeders to experience substantial losses. Therefore, it is necessary to evaluate the implementation of the biosecurity system in the region and how the attitudes of the breeders toward the system.

\section{Research Method}

As a center for laying hens, this research was conducted in Lendah District, Kulonprogo Regency. Respondents were determined using the census method. The application of the biosecurity system is measured using a rating scale. Meanwhile, Spearman's correlation analysis was used to examine the relationship between biosecurity system implementation and mortality. Meanwhile, to determine the attitude of farmers towards the application of the biosecurity system, an analysis of cognitive, affective, and conative aspects was carried out.

\section{Result and Discussion}

\subsection{The Implementation of the Biosecurity System for Layer Chicken Farmin in Lendah District}

The implementation of the biosecurity system can be seen from nine aspects, that is the cleanliness of the cages and the environment, the cleanliness of the drinking places, the cleanliness of the feeding places, vaccination, waste management, sick chicken management, dead chicken management, quarantine measures, and the application of traffic control.

\subsection{The Cleanliness of the Cages and the Environment}

The criteria for evaluating the cleanliness of the cage and the environment consist of three aspects, that were hygiene conditions, use of disinfectants, and cleaning period.

The cleanliness conditions of the coop and the environment for laying hens in Lendah District are in the medium category. This means that the breeders have not fully implemented the biosecurity system, especially in the aspects of cleanliness of cages and the environment. 
Table 1. Assessment of Cages and Environment Conditions of Layer Chicken Farming in Lenda District

\begin{tabular}{|l|c|c|c|}
\hline \multirow{2}{*}{ Assessment Criteria } & \multicolumn{3}{|c|}{ Score } \\
\cline { 2 - 4 } & Good & Fair & Poor \\
\hline \multirow{2}{*}{ Cleanliness conditions } & 0 & 16 & 5 \\
\cline { 2 - 4 } & 0 & 10 & 4 \\
\hline \multirow{2}{*}{ Disinfectant usage } & 36 & 0 & 1 \\
\cline { 2 - 4 } & 24 & 0 & 1 \\
\hline Cleaning period & 3 & 14 & 5 \\
\cline { 2 - 4 } & 6 & 6 & 4 \\
\hline Total Score & \multicolumn{3}{|c|}{$\mathbf{1 3 5}$} \\
\hline Category & \multicolumn{3}{|c}{} \\
\hline
\end{tabular}

\subsection{The Cleanliness of the Drinking Places}

As with the cleanliness of the coop and the environment, the criteria for evaluating the cleanliness of the place to drink chickens also include hygiene conditions, use of disinfectants, and cleaning period.

Table 2. Assessment of Drinking Place Conditions of Layer Chicken Farming in Lendah District

\begin{tabular}{|l|c|c|c|}
\hline \multirow{2}{*}{ Assessment Criteria } & \multicolumn{3}{|c|}{ Score } \\
\cline { 2 - 4 } & Good & Fair & Poor \\
\hline Cleanliness conditions & 30 & 4 & 1 \\
\cline { 2 - 4 } & 21 & 4 & 0 \\
\hline Disinfectant usage & 36 & 0 & 1 \\
\cline { 2 - 4 } & 24 & 0 & 1 \\
\hline Cleaning period & 30 & 4 & 1 \\
\cline { 2 - 4 } & 21 & 2 & 1 \\
\hline Total Score & \multicolumn{3}{|c|}{ Fair } \\
\hline Category & \multicolumn{3}{|c}{} \\
\hline
\end{tabular}

Table 2 shows the scores obtained from the results of the assessment of drinking place conditions. The score obtained is 181 which indicates that the cleanliness of the drinking place is in moderate condition. This condition indicates that several things have not been properly addressed or implemented. In addition, this condition is an accumulative result of three aspects of assessment of the variable conditions of drinking places, that is the condition of cleanliness, use of disinfectants, and time to clean drinking places.

\subsection{The Cleanliness of the Feeding Places}

Like the two previous aspects, the cleanliness of the feeding places was also examined through the cleanliness conditions, disinfectant usage, and cleaning period.

Table 3 shows that the score of the feeding place conditions was 132, which belonged to the fair category. This condition was due to the breeders' lack of attention to the conditions of feeding places and appropriate cleaning methods, especially during the cleaning period. This fair condition was the accumulative result of cleanliness, disinfectant usage, and cleaning period. 
Table 3. Assessment of Feeding Place Conditions of Layer Chicken Farming in Lendah District

\begin{tabular}{|l|c|c|c|}
\hline \multirow{2}{*}{ Assessment Criteria } & \multicolumn{3}{|c|}{ Score } \\
\cline { 2 - 4 } & Good & Fair & Poor \\
\hline Cleanliness conditions & 3 & 20 & 2 \\
\cline { 2 - 4 } & 3 & 14 & 1 \\
\hline Disinfectant usage & 36 & 0 & 1 \\
\cline { 2 - 4 } & 24 & 0 & 1 \\
\hline Cleaning period & 0 & 6 & 10 \\
\cline { 2 - 4 } & 0 & 4 & 7 \\
\hline Total Score & \multicolumn{3}{|c|}{ Fair } \\
\hline Category & \multicolumn{3}{|c}{} \\
\hline
\end{tabular}

\subsection{Vaccination}

The aspect of vaccination in this study was investigated from how breeders vaccinated their layer chickens.

Table 4. Assessment of Vaccination Implementation in Layer Chicken Farming in Lendah District

\begin{tabular}{|l|c|c|c|}
\hline \multirow{2}{*}{ Assessment Criteria } & \multicolumn{3}{|c|}{ Score } \\
\cline { 2 - 4 } & Good & Fair & Poor \\
\hline Vaccination implementation & 36 & 0 & 1 \\
\cline { 2 - 4 } & 24 & 0 & 1 \\
\hline Total Score & \multicolumn{3}{|c|}{ 62 } \\
\hline Category & \multicolumn{3}{|c|}{ Good } \\
\hline
\end{tabular}

This aspect score is 62 which is in the good category. Officers from the poultry office vaccinate $91 \%$ of laying hens in Lendah District. However, some breeders were found not to vaccinate their laying hens. Vaccination aims to prevent chickens from developing various diseases. The correct dose and method of vaccination certainly has a positive impact on the condition of the chicken.

\subsection{Waste Management}

The method and time of handling waste were the two criteria evaluated in the aspect of waste management.

Table 5. Assessment of Waste Management of Layer Chicken Farming in Lendah District

\begin{tabular}{|l|c|c|c|}
\hline \multirow{2}{*}{ Assessment Criteria } & \multicolumn{3}{|c|}{ Score } \\
\cline { 2 - 4 } & Good & Fair & Poor \\
\hline \multirow{2}{*}{ Handling Method } & 39 & 0 & 0 \\
\cline { 2 - 4 } & 27 & 0 & 0 \\
\hline Retrieval Time & 0 & 8 & 4 \\
\cline { 2 - 4 } & 0 & 10 & 97 \\
\hline Total Score & \multicolumn{3}{|c|}{ Fair } \\
\hline Category & \multicolumn{3}{|c|}{} \\
\hline
\end{tabular}

Table 5 provides an overview of the conditions of waste management in laying hens in Lendah district. The score obtained is 97 , and is included in the medium category. This means that farmers have handled the waste properly. However, in terms of the timing of 
collecting waste from the cages, most of the conditions are very poor. The aspects assessed are how it is handled and when to collect or clean trash from the cage.

\subsection{Sick Chicken Management}

The conditions of sick chicken management were seen from how breeders handled the sick chickens. Data regarding this aspect are presented in the following table:

Table 6. Assessment of Sick Chicken Management of Layer Chicken Farming in Lendah District

\begin{tabular}{|l|c|c|c|}
\hline \multirow{2}{*}{ Assessment Criteria } & \multicolumn{3}{|c|}{ Score } \\
\cline { 2 - 4 } & Good & Fair & Poor \\
\hline \multirow{2}{*}{ Handling Method } & 9 & 20 & 0 \\
\cline { 2 - 4 } & 3 & 16 & 0 \\
\hline Total Score & \multicolumn{3}{|c|}{ Fair } \\
\hline Category & \multicolumn{3}{|c}{} \\
\hline
\end{tabular}

The score obtained was 48 , in which the category was fair. As many as $18 \%$ of breeders had handled the sick chickens properly by separating them from healthy chickens and providing treatment for them. While $82 \%$ of them belonged to the fair category, indicating that they had not separated the sick chickens from the healthy ones. Sick chickens require specific treatment to prevent transmission to other healthy chickens. According to FAO, sick chickens should be placed in a closed room without contact with other chickens. Furthermore, Ambarwati added that sick chickens should be kept away or placed in quarantine cages separated from healthy chicken coops [5].

\subsection{Chicken Management}

The evaluation of dead chicken management was seen from how the breeders handled dead chickens.

Table 7. Assessment of Dead Chicken Management of Layer Chicken Farming in Lendah District

\begin{tabular}{|l|c|c|c|}
\hline \multirow{2}{*}{ Assessment Criteria } & \multicolumn{3}{|c|}{ Score } \\
\cline { 2 - 4 } & Good & Fair & Poor \\
\hline Handling Method & 39 & 0 & 0 \\
\cline { 2 - 4 } & 27 & 0 & 0 \\
\hline Total Score & \multicolumn{3}{|c|}{ G6 } \\
\hline Category & \multicolumn{3}{|c|}{} \\
\hline
\end{tabular}

The score obtained was 66, and the category was good. All layer chicken breeders in Lendah District immediately took the dead chickens for burning or burial. According to Ambarwati, dead chickens need to be burned to avoid contracting the diseases to other healthy chickens and become a very harmful source of disease [6].

\subsection{New Chicken Quarantine Management}

The evaluation of quarantine actions was assessed from how and how long the new chickens were placed separately from the old ones. 
Table 8. Quarantine Management of Layer Chicken Farming in Lendah District

\begin{tabular}{|l|c|c|c|}
\hline \multirow{2}{*}{ Assessment Criteria } & \multicolumn{3}{|c|}{ Score } \\
\cline { 2 - 4 } & Good & Fair & Poor \\
\hline Quarantine Action & 39 & 0 & 0 \\
\cline { 2 - 4 } & 27 & 0 & 0 \\
\hline Total Score & \multicolumn{3}{|c|}{ Good } \\
\hline Category & \multicolumn{3}{|c|}{} \\
\hline
\end{tabular}

Obtaining a total score of 66 , the treatment of new chicken belonged to the good category. Overall, the breeders did the separation or commonly called quarantine of new chickens. They did not immediately mix the new chickens with the old or the existing ones. Quarantine action on new chickens was required to prevent transmission of the disease. New farm animals have the potential to carry viruses and need to be separated without prior contact with existing chickens.

\subsection{Traffic Control}

The assessment of traffic control conditions was evaluated from the implementation of traffic control carried out by the breeders.

Table 9. Assessment of Traffic Control of Layer Chicken Farming in Lendah District

\begin{tabular}{|l|c|c|c|}
\hline \multirow{2}{*}{ Assessment Criteria } & \multicolumn{3}{|c|}{ Score } \\
\cline { 2 - 4 } & Good & Fair & Poor \\
\hline \multirow{2}{*}{ Traffic Control Implementation } & 0 & 12 & 7 \\
\cline { 2 - 4 } & 0 & 4 & 7 \\
\hline Total Score & \multicolumn{3}{|c|}{ Poor } \\
\hline Category & \multicolumn{3}{|c|}{} \\
\hline
\end{tabular}

The score obtained from the implementation of traffic control was 30, which belonged to the category of bad. There was only a makeshift fence used as a barrier to avoid other animals to enter. The number of breeders implementing traffic control was $36 \%$. It was similar to broiler breeders in China in which only $47 \%$ of them controlled the traffic by controlling wild birds and rodents from entering their farms. Birds and wild rodents could be intermediaries for the transmission of poultry, so they could be infected with viruses [7]. Breeders needed to avoid direct contact between poultry and livestock with disease sources. This method was done by limiting contact between humans, equipment used, and other animals.

\subsection{The Overall Implementation of the Biosecurity System}

After each assessment aspect of the biosecurity level of layer chicken farming in Lendah District was found, then the overall implementation of the biosecurity system was examined.

In general, the implementation of the biosecurity system in layer chicken farming in Lendah District belonged to the category of fair. However, several aspects (44\%), such as the cleanliness of the cages and the environment, implementation of vaccinations, dead chicken management, and quarantine measures, belonged to the category of good. Meanwhile, several others (44\%) belonging to the category of fair were the cleanliness of drinking places, cleanliness of feeding places, farming waste management, and sick chicken management. Furthermore, the aspect of applying traffic control belonged to the category 
of poor, which was $12 \%$. These results are in line with research stating that traffic control was not good, such as too many visitors or employers coming to the farm location without paying attention to the cleanliness, which would make poultry more easily infected with the diseases [8]. It is also strengthened by the results of research [9] mentioning that good traffic control was considered as the most effective action, and maintaining regular contact with a veterinarian was the most practical action.

Table 10. Assessment of the Overall Implementation of Biosafety in Layer Chicken Farming in Lendah District

\begin{tabular}{|l|c|c|l|}
\hline Biosecurity Aspects & Score & Percentage (\%) & Category \\
\hline Cleanliness conditions of the cages and the environment & 135 & 68 & Fair \\
\hline Cleanliness conditions of drinking places & 181 & 91 & Fair \\
\hline Cleanliness conditions of feeding places & 132 & 67 & Fair \\
\hline Vaccination & 62 & 94 & Good \\
\hline Chicken waste management & 97 & 73 & Fair \\
\hline Sick chicken management & 48 & 73 & Fair \\
\hline Dead chicken management & 66 & 100 & Good \\
\hline Quarantine action & 66 & 100 & Good \\
\hline Traffic control implementation & 30 & 45 & Poor \\
\hline Total Score and Category & $\mathbf{8 1 7}$ & & Fair \\
\hline
\end{tabular}

The implementation of the biosecurity system needed to be improved to reduce the death rate caused by Tetelo disease. Biosecurity is a system that, if implemented maximally and adequately, will prevent chickens from getting attacked by diseases and death [10].

\subsection{The Success Rate of Implementing the Biosecurity System}

The success rate of implementing the biosecurity system in layer chicken farming could be seen from the level of mortality. The better the implementation of the system, the lower the mortality rate of layer chickens.

Table 11. Mortality Rate of Layer Chicken Farming in Lendah District

\begin{tabular}{|l|c|}
\hline Mortality Rate (\%) & Percentage (\%) \\
\hline$\leq 7 \%$ & $18 \%$ \\
\hline$>7 \%$ & $82 \%$ \\
\hline Total & $\mathbf{1 0 0 \%}$ \\
\hline
\end{tabular}

The mortality rate for laying hens in Lendah district is quite high. In most of the farms $(83 \%)$ in the area, the mortality rate is more than $7 \%$. The maximum standard of mortality for chickens that apply the biosecurity system is $7 \%$ [11]. Thus, the success of breeders in implementing a biosecurity system properly was only $18 \%$. Likewise in the UK, where poultry farmers implement the biosecurity system in only one or two actions and do not do it comprehensively. This is due to the lack of knowledge of farmers about the biosecurity system. For example, breeders feed their animals with kitchen scraps and do not know how to handle dead animals [12]. The implementation of a better biosecurity system will reduce the mortality rate of laying hens. This is consistent with the results of research conducted by Sadarman, Wahyuni, Tabbu, and Budhiarta which showed that farms that apply a good biosecurity system have a lower risk of developing disease [13]. To prove that the level of biosecurity conditions affects mortality, a Spearman correlation analysis was performed. 
Table 12. The Results of Spearman Correlation Analysis Between the Implementation of the Biosecurity System and Mortality Rates

\begin{tabular}{|l|c|c|}
\hline \multicolumn{3}{|c|}{ Spearman's Rho } \\
\hline & Level of Biosecurity Conditions & Mortality Rates \\
\hline Correlation Coefficient & 1.000 & -.626 \\
\hline $\mathbf{N}$ & 22 & 22 \\
\hline
\end{tabular}

The correlation coefficient of -0.626 indicates that the level of biosecurity system implementation and mortality rates have a strong relationship or correlation. This means that the better the application of the biosecurity system, the lower the mortality rate for laying hens. There is a strong and significant relationship between the level of knowledge and the effectiveness of the Farmer Card Program, with a coefficient of 0.568. [14]

\subsection{Breeders' Attitudes toward the System and the Implementation of Biosecurity in Layer Chicken Farming in Lendah District}

Attitude is a person's tendency towards an object which consists of thoughts and feelings about things that are liked or disliked, known or unknown, and even interesting or unattractive. Attitude contains three aspects, namely cognitive, affective, and conative.

The biosecurity system is the knowledge of layer hen farmers in Lendah District about biosecurity which includes its general understanding.

Table 13. Breeders' Cognitive Attitudes toward the System of the Biosecurity in Layer Chicken Farming in Lendah District

\begin{tabular}{|l|l|c|c|c|c|c|c|c|}
\hline \multirow{2}{*}{ No } & \multicolumn{1}{|c|}{ Item } & \multicolumn{4}{|c|}{$\begin{array}{l}\text { Respondent } \\
\text { Distribution }\end{array}$} & $\begin{array}{l}\text { Score } \\
\text { Range }\end{array}$ & $\begin{array}{c}\text { Average of } \\
\text { Score } \\
\text { Acquisition }\end{array}$ & Category \\
\cline { 3 - 8 } & & DK & U & K & KW & & 2.73 & \\
\hline 1 & $\begin{array}{l}\text { The purposes of the } \\
\text { biosecurity system for layer } \\
\text { chicken breeders in general }\end{array}$ & 0 & 6 & 16 & 0 & $1-4$ & & \\
\hline 2 & $\begin{array}{l}\text { The benefits of } \\
\text { implementing the } \\
\text { biosecurity system in } \\
\text { general }\end{array}$ & 0 & 13 & 9 & 0 & $1-4$ & 2.41 & \\
\hline 3 & $\begin{array}{l}\text { The scope of the biosecurity } \\
\text { system }\end{array}$ & 0 & 13 & 9 & 0 & $1-4$ & 2.41 & \\
\hline Total & & & & & $\mathbf{3 - 1 2}$ & $\mathbf{7 . 5 5}$ & Know \\
\hline
\end{tabular}

Source: Primary Data 2019

Breeders who were unaware of the objectives of the biosecurity system were those having a low level of education. Education influences one's knowledge, which means the higher one's education, the higher the person's knowledge.

The majority of layer chicken breeders knowing the benefits of the biosecurity system were the new breeders. In other words, they had new experiences concerning chicken farming. After learning about biosecurity, they became breeders and began implementing the system in their chicken farming.

Breeders knowing about vaccination and the importance of cleanliness of the cages were those having an average of 5,000 chickens and more than that.

Breeders who clean the environment around the cage are breeders who are highly educated, namely high school and bachelor degrees. Education level plays an important role in increasing farmers' knowledge about poultry health. Farmers who have good management of sick chickens are those who have quite a long experience of raising chickens, which is more than 20 years. This shows that the experience of raising chickens 
helps them in managing sick chickens. This is in line with the research [... numbering ...] conducted by Thi Tam Duong et al. in their study entitled Understanding the Intention the Intention to Use Biosecurity Management Strategies On-Farm: A study of Vietnamese Farmers in Australia which stated that farmers with more farming experience tended to better adopt biosecurity risk management strategies.

Table 14. Breeders' Cognitive Attitudes toward the Implementation of the Biosecurity System in Layer Chicken Farming in Lendah District

\begin{tabular}{|c|c|c|c|c|c|c|c|c|}
\hline \multirow[t]{2}{*}{ No } & \multirow[t]{2}{*}{ Item } & \multicolumn{4}{|c|}{$\begin{array}{l}\text { Respondent } \\
\text { Distribution }\end{array}$} & \multirow[t]{2}{*}{$\begin{array}{l}\text { Score } \\
\text { Range }\end{array}$} & \multirow{2}{*}{$\begin{array}{l}\text { Average of } \\
\text { Score } \\
\text { Acquisition }\end{array}$} & \multirow[t]{2}{*}{ Category } \\
\hline & & DK & $\mathbf{U}$ & $\mathbf{K}$ & KW & & & \\
\hline 1 & $\begin{array}{l}\text { Vaccination in the } \\
\text { biosecurity system }\end{array}$ & 0 & 13 & 9 & 0 & $1-4$ & 2.41 & \\
\hline 2 & $\begin{array}{l}\text { Cage cleanliness in the } \\
\text { biosecurity system }\end{array}$ & 0 & 13 & 9 & 0 & $1-4$ & 2.41 & \\
\hline 3 & $\begin{array}{l}\text { Cleanliness outside the } \\
\text { cages in the biosecurity } \\
\text { system }\end{array}$ & 0 & 20 & 2 & 0 & $1-4$ & 2.09 & \\
\hline 4 & $\begin{array}{l}\text { Management of disease- } \\
\text { affected chickens in the } \\
\text { biosecurity system }\end{array}$ & 0 & 16 & 6 & 0 & $1-4$ & 2.27 & \\
\hline 5 & $\begin{array}{l}\text { Cleanliness of feeding } \\
\text { and drinking places in } \\
\text { the biosecurity system }\end{array}$ & 0 & 17 & 5 & 0 & $1-4$ & 2.23 & \\
\hline 6 & $\begin{array}{l}\text { Management of chicken } \\
\text { waste in the biosecurity } \\
\text { system }\end{array}$ & 0 & 20 & 2 & 0 & $1-4$ & 2.09 & \\
\hline 7 & $\begin{array}{l}\text { Management of dead } \\
\text { chickens in the } \\
\text { biosecurity system }\end{array}$ & 5 & 17 & 0 & 0 & $1-4$ & 1.77 & \\
\hline 8 & $\begin{array}{l}\text { Quarantine of new } \\
\text { chickens in the } \\
\text { biosecurity system }\end{array}$ & 12 & 9 & 1 & 0 & $1-4$ & 1.50 & \\
\hline 9 & $\begin{array}{l}\text { Traffic control in the } \\
\text { biosecurity system }\end{array}$ & 15 & 7 & 0 & 0 & $1-4$ & 1.32 & \\
\hline & Total & & & & & $9-36$ & 18.09 & Do not know \\
\hline
\end{tabular}

Source: Primary Data 2019

Breeders knowing how to quarantine new chickens were those having less than 5 years of experience. Having quite good knowledge, they quarantined new chickens at the beginning of the breeding.

\subsection{Total Cognitive Attitudes}

Table 15. Total Cognitive Attitudes of Layer Chicken Breeders in Lendah District

\begin{tabular}{|c|c|c|c|}
\hline Cognitive Attitudes & Score Range & Score Acquisition & Category \\
\hline Biosecurity system & $3-12$ & 7.55 & \\
\hline Implementation & $9-36$ & 1.09 & \\
\hline Total & $\mathbf{1 2 - 4 8}$ & $\mathbf{2 5 . 6 4}$ & Do not know \\
\hline
\end{tabular}

Source: Primary Data 2019

The discussion of each aspect resulted in the total cognitive attitudes score of 25.64, which belonged to the category of do not know. It indicates that layer chicken breeders in 
Lendah District had no sufficient knowledge regarding the system and the implementation of biosecurity in their farming. They did not know the concept and the conditions of biosecurity used as the indicators to determine their cognitive attitudes on this issue.

Table 16. Breeders' Affective Attitudes toward the Biosecurity System in Layer Chicken Farming in Lendah District

\begin{tabular}{|c|l|c|c|c|c|c|c|c|}
\hline \multirow{2}{*}{ No } & \multicolumn{1}{|c|}{ Item } & \multicolumn{3}{|c|}{$\begin{array}{c}\text { Respondent } \\
\text { Distribution }\end{array}$} & $\begin{array}{c}\text { Score } \\
\text { Range }\end{array}$ & $\begin{array}{c}\text { Average of } \\
\text { Score } \\
\text { Acquisition }\end{array}$ & Category \\
\cline { 2 - 7 } & D & N & A & SA & & \\
\hline 1 & $\begin{array}{l}\text { The purposes of the } \\
\text { biosecurity system for } \\
\text { layer chicken breeders } \\
\text { in general }\end{array}$ & 0 & 0 & 20 & 2 & $1-4$ & 3.09 & \\
\hline 2 & $\begin{array}{l}\text { The benefits of } \\
\text { implementing the } \\
\text { biosecurity system in } \\
\text { general }\end{array}$ & 0 & 0 & 20 & 2 & $1-4$ & 3.09 & \\
\hline 3 & $\begin{array}{l}\text { The scope of the } \\
\text { biosecurity system }\end{array}$ & 0 & 0 & 21 & 1 & $1-4$ & 3.05 & \\
\hline & \begin{tabular}{l} 
Total \\
\hline
\end{tabular} & & & & & $\mathbf{3 - 1 2}$ & $\mathbf{9 . 2 3}$ & Agree \\
\hline
\end{tabular}

Farmers who responded strongly to the goals and benefits of biosecurity systems were those with higher education levels. This becomes a reference that education affects a person's response in accepting or approving something. The responses of farmers to the application of biosecurity, with indicators disagree to strongly agree, are presented in the following table.

Table 17. Breeders' Affective Attitudes toward the Implementation of the Biosecurity System in Layer Chicken Farming in Lendah District

\begin{tabular}{|c|l|c|c|c|c|c|c|c|}
\hline No & \multicolumn{1}{|c|}{ Item } & \multicolumn{3}{|c|}{$\begin{array}{l}\text { Respondent } \\
\text { Distribution }\end{array}$} & $\begin{array}{l}\text { Score } \\
\text { Range }\end{array}$ & $\begin{array}{c}\text { Average of } \\
\text { Score } \\
\text { Acquisition }\end{array}$ & Category \\
\cline { 3 - 7 } & & D & N & A & SA & & 3.05 & \\
\hline 1 & $\begin{array}{l}\text { Vaccination in the biosecurity } \\
\text { system }\end{array}$ & 0 & 0 & 21 & 1 & $1-4$ & 3.05 & \\
\hline 2 & $\begin{array}{l}\text { Cage cleanliness in the } \\
\text { biosecurity system }\end{array}$ & 0 & 0 & 21 & 1 & $1-4$ & 3.05 & \\
\hline 3 & $\begin{array}{l}\text { Cleanliness outside the cages } \\
\text { in the biosecurity system }\end{array}$ & 0 & 0 & 21 & 1 & $1-4$ & 3.05 & \\
\hline 4 & $\begin{array}{l}\text { Management of disease- } \\
\text { affected chickens in the } \\
\text { biosecurity system }\end{array}$ & 0 & 0 & 21 & 1 & $1-4$ & & \\
\hline 5 & $\begin{array}{l}\text { Cleanliness of feeding and } \\
\text { drinking places in the } \\
\text { biosecurity system }\end{array}$ & 0 & 0 & 21 & 1 & $1-4$ & 3.05 & \\
\hline 6 & $\begin{array}{l}\text { Management of chicken waste } \\
\text { in the biosecurity system }\end{array}$ & 0 & 0 & 22 & 0 & $1-4$ & 3.00 & \\
\hline 7 & $\begin{array}{l}\text { Management of dead chickens } \\
\text { in the biosecurity system }\end{array}$ & 0 & 0 & 22 & 0 & $1-4$ & 3.00 & \\
\hline 8 & $\begin{array}{l}\text { Quarantine of new chickens in } \\
\text { the biosecurity system }\end{array}$ & 0 & 0 & 22 & 0 & $1-4$ & 3.00 & \\
\hline 9 & $\begin{array}{l}\text { Traffic control in the } \\
\text { biosecurity system }\end{array}$ & 0 & 0 & 22 & 0 & $1-4$ & 3.00 & \\
\hline & Total & & & & & $\mathbf{9 - 3 6}$ & $\mathbf{2 7 . 2 3}$ & Agree \\
\hline
\end{tabular}

Source: Primary Data 2019 
One respondent who strongly agrees with the application of the biosecurity system has an undergraduate education background. Education is important to open knowledge and better insights to provide the right response. In line with research conducted by T. Van Limbergen et al. stated that better education for broiler breeders and their staff could help improve the overall biosecurity system in broiler farms in Europe [15].

\subsection{Total Affective Attitudes}

Table 18. Total Affective Attitudes of Layer Chicken Breeders in Lendah District

\begin{tabular}{|l|l|l|l|}
\hline \multicolumn{1}{|c|}{ Affective Attitudes } & \multicolumn{1}{|c|}{ Score Range } & Score Acquisition & Category \\
\hline Biosecurity system & $3-12$ & 9.23 & \\
\hline Implementation & $9-36$ & 27.23 & \\
\hline Total & $\mathbf{1 2 - 4 8}$ & $\mathbf{3 6 . 4 6}$ & Agree \\
\hline
\end{tabular}

Source: Primary Data 2019

Based on the discussion of each indicator, the total affective attitude has a score of 36.46 and is included in the agree category. This means that most layer chicken farmers in Lendah district agree with the general knowledge, implementation, and conditions of the biosecurity system. Their response was said to be good because the majority agreed with the system. However, in its implementation, they have not fully implemented the system properly. According to Thi Tam Duong et al., In their research, a policy is needed to select the right breeders in order to effectively facilitate their intention to adopt biosecurity measures [16].

A conative attitude can be interpreted as a tendency of behavior or interest in layer hen farmers in Lendah District to biosecurity systems. The farmer's conative attitude towards the biosecurity system is presented in the following table:

Table 19. Breeders' Conative Attitudes toward the Biosecurity Systems in Layer Chicken Farming in Lendah District

\begin{tabular}{|c|l|c|c|c|c|c|c|c|}
\hline No & \multicolumn{1}{|c|}{ Item } & \multicolumn{3}{|c|}{$\begin{array}{c}\text { Respondent } \\
\text { Distribution }\end{array}$} & $\begin{array}{c}\text { Score } \\
\text { Range }\end{array}$ & $\begin{array}{c}\text { Average of } \\
\text { Score } \\
\text { Acquisition }\end{array}$ & Category \\
\cline { 3 - 8 } & DK & U & K & KW & & 3.41 & \\
\hline 1 & $\begin{array}{l}\text { The purposes of the } \\
\text { biosecurity system for } \\
\text { layer chicken } \\
\text { breeders in general }\end{array}$ & 0 & 0 & 13 & 9 & $1-4$ & & \\
\hline 2 & $\begin{array}{l}\text { The benefits of } \\
\text { implementing the } \\
\text { biosecurity system in } \\
\text { general }\end{array}$ & 0 & 0 & 14 & 8 & $1-4$ & 3.36 & \\
\hline 3 & $\begin{array}{l}\text { The scope of the } \\
\text { biosecurity system }\end{array}$ & 0 & 0 & 14 & 8 & $1-4$ & 3.36 & \\
\hline & Total & & & & & $\mathbf{3 - 1 2}$ & $\mathbf{1 0 . 1 3}$ & Very interested \\
\hline
\end{tabular}

Overall, respondents involved in this study were very interested in biosecurity systems especially in terms of goals and benefits for laying hens. They are particularly interested in biosecurity purposes that help minimize diseases that can attack chickens and help farmers to reduce the number of dead chickens or lower the mortality rate of chickens on poultry farms. Similarly, organic dairy farmers in Denmark adopted a biosecurity system with the priority of controlling endemic local essential diseases, and outbreaks of diseases that occurred at the time, namely mastitis, digital dermatitis, salmonellosis and mycoplasmosis [17]. 
Table 20. The Implementation of the Biosecurity System in Layer Chicken Farming in Lendah District

\begin{tabular}{|c|c|c|c|c|c|c|c|c|}
\hline \multirow[t]{2}{*}{ No } & \multirow[t]{2}{*}{ Item } & \multicolumn{4}{|c|}{$\begin{array}{l}\text { Respondent } \\
\text { Distribution }\end{array}$} & \multirow[t]{2}{*}{$\begin{array}{l}\text { Score } \\
\text { Range }\end{array}$} & \multirow{2}{*}{$\begin{array}{l}\text { Average of } \\
\text { Score } \\
\text { Acquisition }\end{array}$} & \multirow[t]{2}{*}{ Category } \\
\hline & & NI & $\mathbf{U}$ & I & VI & & & \\
\hline 1 & $\begin{array}{l}\text { Vaccination in the } \\
\text { biosecurity system }\end{array}$ & 0 & 0 & 14 & 8 & $1-4$ & 3.36 & \\
\hline 2 & $\begin{array}{l}\text { Cage cleanliness in the } \\
\text { biosecurity system }\end{array}$ & 0 & 0 & 14 & 8 & $1-4$ & 3.36 & \\
\hline 3 & $\begin{array}{l}\text { Cleanliness outside the } \\
\text { cages in the biosecurity } \\
\text { system }\end{array}$ & 0 & 0 & 17 & 5 & $1-4$ & 3.23 & \\
\hline 4 & $\begin{array}{l}\text { Management of disease- } \\
\text { affected chickens in the } \\
\text { biosecurity system }\end{array}$ & 0 & 0 & 17 & 5 & $1-4$ & 3.23 & \\
\hline 5 & $\begin{array}{l}\text { Cleanliness of feeding } \\
\text { and drinking places in } \\
\text { the biosecurity system }\end{array}$ & 0 & 0 & 17 & 5 & $1-4$ & 3.23 & \\
\hline 6 & $\begin{array}{l}\text { Management of chicken } \\
\text { waste in the biosecurity } \\
\text { system }\end{array}$ & 0 & 1 & 17 & 4 & $1-4$ & 3.14 & \\
\hline 7 & $\begin{array}{l}\text { Management of dead } \\
\text { chickens in the } \\
\text { biosecurity system }\end{array}$ & 0 & 0 & 18 & 4 & $1-4$ & 3.18 & \\
\hline 8 & $\begin{array}{l}\text { Quarantine of new } \\
\text { chickens in the } \\
\text { biosecurity system }\end{array}$ & 0 & 0 & 18 & 4 & $1-4$ & 3.18 & \\
\hline 9 & $\begin{array}{l}\text { Traffic control in the } \\
\text { biosecurity system }\end{array}$ & 0 & 0 & 18 & 4 & $1-4$ & 3.18 & \\
\hline & Total & & & & & 9-36 & 29.09 & Interested \\
\hline
\end{tabular}

In general, breeders were very interested in vaccination and sanitation in the biosecurity system. These two factors were the leading indicators influencing the death rate of layer chicken if not carried out appropriately. These results are not in line with cattle farming in Belgium. The results of a study conducted by Bert Damiaans et al. stated that the awareness level of breeders in implementing biosecurity on cattle farming was very low. One indicator seen was that there was no quarantine on calves [18].

\subsection{Total Conative Attitudes}

Table 21. Total Conative Attitudes of Layer Chicken Breeders in Lendah District

\begin{tabular}{|l|c|c|c|}
\hline \multicolumn{1}{|c|}{ Conative Attitudes } & Score Range & Score Acquisition & Category \\
\hline Biosecurity system & $3-12$ & 10.13 & \\
\hline Implementation & $9-36$ & 29.09 & \\
\hline Total & $\mathbf{1 2 - 4 8}$ & $\mathbf{3 9 . 2 3}$ & Very interested \\
\hline
\end{tabular}

The discussion of each indicator resulted in the total conative attitudes score of 39.23 and belonged to the category of very interested. It indicates that most of the layer chicken breeders in Lendah District were very interested in the biosecurity system, particularly regarding the general knowledge, implementation, and the conditions. These three aspects were the indicators to determine their interest in the biosecurity system. 


\subsection{Breeders' Attitudes toward the Overall Biosecurity System}

The overall process of evaluating and analyzing attitudes included three components, namely cognitive (knowledge), affective (feeling), and conative (tendency to act).

Table 22. The Overall Attitudes of Layer Chicken Breeders in Lendah District toward the Biosecurity System

\begin{tabular}{|l|c|c|l|}
\hline Attitudes & Score Range & Score Acquisition & Category \\
\hline Cognitive & $12-48$ & 25.64 & Do not know \\
Affective & $12-48$ & 36.45 & Agree \\
\hline Conative & $12-48$ & 39.23 & Very interested \\
\hline Total & $\mathbf{1 2 - 4 8}$ & $\mathbf{1 0 1 . 3 2}$ & Good \\
\hline
\end{tabular}

Source: Primary Data 2019

The total score of breeders' attitudes toward the biosecurity system was 101.32 , which belonged to the category of good. It was because breeders agreed and were very interested in the system and the implementation of the biosecurity system in layer chicken farming. According to Adit Mankad (2019), in his research in North Australia, there were more breeders in the area implementing the biosecurity system due to an agreement within the groups and activities carried out by fellow breeders in their land [19] .

\section{Conclusion and Suggestion}

1. The implementation of the biosecurity system in layer chicken farming in Lendah District as a whole was in fair (moderate) condition because most of the breeders paid less attention to sanitation aspects such as the cleanliness of feeding places and traffic control in their farming.

2. In general, the application of the biosecurity system on layer hens in Lendah district has not been successful.

3. The implementation level of the biosecurity system in layer chicken farming in Lendah District was strongly related to the level of chicken mortality.

4. The attitudes of breeders toward the biosecurity system were quite good, and they were interested in applying the system to their layer chicken farming.

5. The related parties should pay attention and assist breeders in implementing the biosecurity system properly based on the existing guidelines. Thus, breeders can implement the biosecurity system maximally to reduce the chicken mortality rate.

\section{References}

1. U. Hadi, Pelaksanaan Biosecurity Pada Peternakan Ayam. (IPB, Bogor, 2010).

2. Nurcholis, Mediagro 5, 38 (2009).

3. B. Cui, Z. P. Liu, J. Ke, and Y. Tian, Prev. Vet. Med. 167, 25 (2019).

4. A. Conan, F. L. Goutard, D. Holl, S. Ra, A. Ponsich, A. Tarantola, S. Sorn, and S. Vong, Vet. J. 198, 649 (2013).

5. Y. Ambarwati, (2016).

6. M. Setyono, D. J., \& Ulfah, 7 Jurus Sukses Menjadi Peternak Ayam Ras Pedaging (Penebar Swadaya, Jakarta, 2011).

7. Z. ying HUANG, A. Loch, C. Findlay, and J. min WANG, J. Integr. Agric. 16, 181 (2017).

8. S. Van Steenwinkel, S. Ribbens, E. Ducheyne, E. Goossens, and J. Dewulf, Prev. Vet. Med. 98, 259 (2011).

9. O. Shortall, M. Green, M. Brennan, W. Wapenaar, and J. Kaler, J. Dairy Sci. 100, 2225 (2017). 
10. Sutomo, 99\% Gagal Beternak Ayam Petelur (Penebar Swadaya, Jakarta, 2016).

11. Adnan, (2015).

12. C. Correia-Gomes and N. Sparks, Prev. Vet. Med. 174, 104812 (2020).

13. S. Sadarman, Wahyuni, A. E., Tabbu, C. R., \& Budhiarta, J. Peternak. 8, 6 (2011).

14. R. S. Jorgi, S. Gayatri, and T. Dalmiyatun, Agrar. J. Agribus. Rural Dev. Res. 5, (2019).

15. T. Van Limbergen, J. Dewulf, M. Klinkenberg, R. Ducatelle, P. Gelaude, J. Méndez, K. Heinola, S. Papasolomontos, P. Szeleszczuk, and D. Maes, Poult. Sci. 97, 74 (2018).

16. T. T. Duong, J. Luck, and K. K. Zander, Soc. Sci. J. (2019).

17. V. H. S. Oliveira, I. Anneberg, H. Voss, J. T. Sørensen, and P. T. Thomsen, Livest. Sci. 214, 153 (2018).

18. B. Damiaans, V. Renault, S. Sarrazin, A. C. Berge, B. Pardon, S. Ribbens, C. Saegerman, and J. Dewulf, Prev. Vet. Med. 172, 104768 (2019).

19. A. Mankad, A. Zhang, and M. Curnock, J. Environ. Manage. 232, 851 (2019). 